\title{
Brexit and the temporalities of racism in British higher education
}

\author{
Ethiraj Gabriel Dattatreyan, Goldsmiths, University of London
}

Brexit has brought into visibility various strands of racist thinking and practice that have, for many years, simmered under the surface in British life. Discourse about Brexit reveals an enduring nativist and imperialist sentiment that calls into question British liberalism and its purported multiculturalism. Much writing regarding Brexit has focused on issues of class and urban and rural divides related to the disenfranchised white working class. This piece focuses not only on how race/racism (re)emerges as an important category of experience, but also how it mobilizes young people who have been subject to various forms of violent and everyday racialized exclusion in the UK to voice their discontent and demands publicly and, in some cases, collectively within the context of British higher educational institutions. I focus, in particular, on the temporalities these young people invoke to understand and fight against racism in the Brexit era, and the sort of generational divides they make visible.

Keywords: Brexit, racism, higher education, temporalities

I arrived in London in August of 2016 from the United States, just a few months after the historic referendum that set the stage for the United Kingdom to begin the slow, arduous and uncertain process of leaving the European Union. My impetus to move was to begin a permanent academic job at Goldsmiths, University of London in the Department of Anthropology. I had applied to this post on a whim in April, on the insistence of a good friend in Johannesburg who thought the department and the position suited me. I had no plans, prior to applying for or getting the job, to live in the UK but found myself accepting the position when it was offered. A short time after I accepted the offer, but a few months prior to my move to London, the Brexit referendum took place, deciding by the slightest of margins that the UK should leave the EU.

These last four years of teaching in a British higher education institution and making a life in London, all under the shadow of Brexit, has taught me a great deal. I have spent the time, as any good anthropologist would, comparing and contrasting institutional and academic practices between the US and the UK in a period where both academies face increasing pressure to conform to market logics. I have also learned a lot about how differ- ently anthropology is constituted in the UK than it is in the US, each with its particular histories and specific formulations of a disciplinary canon. Throughout, I have also made observations about life in the former imperial center of London, observations made from my vantage point as a once-removed postcolonial subject from India. I could, no doubt, write quite a bit on each of these lines of thought as they pertain to Brexit and its economic, political, cultural, and historical currents as they reshape borders, reimagine pasts, and assert potential futures. It would likely, however, take a book-length exposition to do so.

For this short essay, then, I will focus on what I think Brexit has revealed regarding the persistent, stubborn relationships between race, empire, and nation. The argument I make is relatively straightforward. Brexit has brought into visibility various strands of racist thinking and practice that have, for many years, simmered under the surface in British life. Brexit has created these conditions precisely because its discourse, which has postulated Britain's separation from Europe as its inevitable conclusion, has also made visible an enduring nativist and imperialist sentiment that calls into question British liberalism and its purported multiculturalism. Much of 
what has been written regarding Brexit and the awakened impetus to "leave" has focused on issues of class and urban and rural divides related to the disenfranchised white working class. For instance, in a forum on Brexit published in the journal Social Anthropology soon after the referendum vote, several of the anthropologist contributors pointed immediately to class divides as the explanatory force for the vote to leave (Green et al. 2016). Less attention has been paid to how persistent racisms and their complex intersections with class, gender, and ethnicity have shaped Brexit and its affects. I suggest that the UK's desire to break from Europe is steeped in nostalgic British exceptionalism and a desire to return to a glorious past and that this desire brings to the surface submerged racisms that endure as a kind of coloniality in the present for not only those deemed "migrants" but for longstanding British black and ethnic minority populations. These racisms amplify class divides and show the limits of British liberalism.

What I find interesting and important is how Brexit has mobilized young people who have been subject to various forms of violent and everyday racialized exclusion in the UK to voice their discontent publicly and, in some cases, collectively. My time in a British university has put me in conversation with a diverse group of students who, since I arrived in 2016, have been vocally and assertively pointing to enduring forms of coloniality in the institutions they traverse and linking these forms of discrimination to broader historical shifts. "BAME" (Black, Asian, and Minority Ethnic) students' articulation of a race problem, specifically within the context British higher education, and their demands for change over the last few years, offer a diagnostic of Brexit's impact, a way to trace colonial, imperial, and postcolonial histories as they animate the politics of the present. ${ }^{1}$ These contours, I suggest, show us the multiple twentieth

1. BAME_-Black, Asian, and Minority Ethnic - is a racial category of the state used to recognize and group nonwhite Britons. I use the category in this essay as a shorthand descriptor even though I have problems with its assumption of sameness across difference. I also use "white," "black," and "brown" as popularly circulating racial categories of self-description. These categories also have the propensity to obfuscate as much as they make visible structures of difference and inequality nationally and transnationally. and twenty-first century temporalities at play when racism is named by young people who have a deep sense of their diasporic positionality and the postcolonial geographies that produce them in relationship to a faded empire and its aspirations for a return to glory.

What do I mean by temporality? Without going into too long an exposition, I am using temporality to mark the ways in which renderings of the past are used to make sense of the present and build futures. As Ann Stoler (2013) remarks and I paraphrase, the past is the ruins by which we cast our visions for the future. Temporality, then, is a way to mark what scales and specificities of history people take up to build their understandings of the present and their visions for the future. The students I met at Goldsmiths and in other London universities mobilized imperial and postcolonial spacetimes to make sense of life during Brexit and inside the university and to imagine different futures. They did so in ways that their white peers and lecturers did not.

Equally important are the ways in which Brexit has exposed a generational divide, in particular around issues of race. In the university, a diverse body of students, with well-developed social media literacies that allow them to link their experiences to others across the globe, are responding quite differently to Brexit than the anti-racist veteran academics in the British academy. The students' take, I found, is one that is instinctively more attentive to transnational histories and the relationships between race, class, and gender. Their understanding and articulation of racism, importantly, also pushed back on faculty who imagine the university and, by extension, Britain as post-racial. In what follows I offer a few brief examples of how-in the interregnum between 2016 and 2019 - various histories were evoked as a way of making sense of the present and future and the ways in which these histories were generationally and positionally differentiated.

When I arrived in August 2016, the news was filled with small stories of racialized aggression and harassment across the country. These stories were fortified by first-hand accounts my British Asian and black friends told me during my first few months in the country, about the kinds of explicit racial taunts and harassment they faced in a post-Brexit referendum climate. Brexit and its discourse on nostalgic imperial pasts and the reclamation of British power and sovereignty had created a platform for thinly veiled (if veiled at all) white supremacist and nativist rhetoric that fuelled verbal and sometimes physical assaults on those not deemed 
British enough. ${ }^{2}$ This rhetoric and its materialized affects brought to the surface what had been simmering under the peculiar variety of post-1980s British postracial liberalism.

Post-racial discourses in the UK, as in the US, suggest that racism is a thing of the past (Holland 2012). They use evidence of individual cases of black and brown success in Western liberal democracies and the banishment of the explicit, unabashed racist talk in the public sphere as their evidence to prove race, as a colonial taxonomy of hierarchical difference and a nation-state logic of disenfranchisement, is no longer salient. Incidents of hateful harassment and violence after the referendum, however, laid bare how untrue the latter was. Specters of white nationalist movements of the past - the National Front, white supremacist skinheads, and so on-reappeared in the national imaginary under new banners. Those I met in the university who had a historical memory of the 1970s and 1980s in London and who fought under an anti-racist banner against these nativist forces shared with me their experiences of the past as a way to reckon with what was happening in the present.

In my first year in London, Les Back and Paul Halliday, for instance, took me under their wing and offered me a deep dive into the local histories of south-east London, where Goldsmiths is located. Through them I learned about significant events in local history such as the Battle of Lewisham and the New Cross Fire, events that marked the struggle for racial justice in the city and the fight against right-wing, nationalist forces. A rendering of these historical events, they suggested, contextualized the current crop of violence, especially when seen in relation to the hostile environment policy, a UK state initiative that sought to discourage immigrants from staying in the UK by making life unbearable for them. This policy, unsurprisingly, ended up equally targeting British-born black and ethnic minorities. Virulent racism, it turned out, was alive and well in the UK and was given fuel through Brexit talk.

Even as these veteran scholar-activists- "elders"who had organized against racism in the not-too-distant past were sharing their stories with me, the students from minority backgrounds I was meeting in the univer-

2. See the UK government report on the increase in hate crimes since the referendum vote. https://assets.publishing .service.gov.uk/government/uploads/system/uploads /attachment_data/file/748598/hate-crime-1718-hosb2018 .pdf\#page $=8$ sity were telling me about the racism they faced inside the institution. Except, for my students it wasn't the specter of the English racist that they wished to make visible. Rather, it was the mundane, everyday experiences they had in the university that they shared with me during office hours and in our time together in the classroom. In recounting these experiences, they painted a very different species of racism, one that was, for all practical purposes, hidden from view except for those who affectively had to experience it. For them, racism didn't have to look like a targeted policy or a group of angry men on a street spouting expletives or throwing punches. Rather, it was something that prevented the realization of inclusion, enfranchisement, and economic uplift through education. The students I met pushed back, as such, on the other tenet of post-racial discourse. This was the notion that enfranchisement and access for all are a given in "multicultural" Britain and that institutional bias had been, for the most part, tackled - most recently through diversity efforts in various industry and institutional settings. In their stories they specifically pointed to Goldsmiths, the institution they attended and paid fees to, as the site of continuing racial discrimination; they also used a particular language that was markedly different than what their anti-racist elders were using.

Concepts like white fragility, microaggression, institutional racism, structural racism, and intersectional racism were at the tips of their tongues. Racism, as Leith Mullings (2005) argues, has been a term in circulation since the postwar period. In various postcolonial and settler colonial contexts, it has been used to draw attention to the kinds of virulent discrimination linked to particular bodies that persisted in the postwar period and beyond, despite a strong push against nineteenthcentury race science and twentieth-century eugenics. I won't go into a long discussion around the history of racism as an analytical and descriptive concept in specific and various contexts here, but suffice it to say that the students I met when I arrived to the UK used racism, along with attached or related terms, as "shortcut" concepts to describe and locate their experiences in London and in the university. These concepts were deployed to engage in discussions regarding the "attainment gap" and the high incidence of "BAME" dropouts in British higher education. ${ }^{3}$ For my students, their purported

3. The attainment gap is a term used to describe the statistical evidence that white students achieve more firsts or 
lack of success had less to do with a "gap" or deficiency on their part than it had to do with the hostility and discrimination they faced within the institutions they attended, and the structures that are in place to evaluate and assess their work. The terms and concepts they used to articulate their positions in relation to the attainment gap and so on were often learned outside of the university space and allowed them to locate their experiences of marginalization in what is understood as a liberal, even progressive, space of the university.

The language they used - as it linked to social media conversations about race across borders - signalled a generational break from those who had fought against racism in the UK in a previous era. For one, the language they were using evinced a globalized sensibility around race/racialization. For these students, their experiences of discrimination in the UK were linked to what they read in tweets, Facebook posts, and Instagram stories about racialized discrimination elsewhere. This global sensibility around race allowed them to see, for instance, anti-racist organizing taking place in South African and American universities as directly relevant to their own conditions of possibility. The students I've met at Goldsmiths and in other London universities over the last several years also were able to recognize how the university is located well within national and transnational politics. Rather than a space seemingly "outside" of the world, a space of refuge and safety from the racists outside, students quickly grasped that the university is a site of struggle. Racism was a key descriptor used to describe the scope of the struggle.

As importantly, the language they utilized recentered institutional forms of discrimination and therefore offered them a means to articulate a different temporality than their anti-racist elders in the university, who, in my time at Goldsmiths, pointed to life in the UK in the 1970s and 1980s as key historical periods that allow us to understand our Brexit present. In late 2017, one student brought to my attention the broadening participation policies that had been enacted in the UK since the early 2000s. Broadening participation was an initiative, supported by government funds, to bring more black and ethnic minority students into higher education institutions, primarily former polytechnics and second

distinctions than their BAME counterparts. See the Universities UK report on the attainment gap and strategies to close it. https://www.universitiesuk.ac.uk/news/Pages /Universities-acting-to-close-BAME-student-attainment -gap.aspx tier, non-Russell Group universities (Boliver 2016). ${ }^{4}$ The student made one comment that stuck in my mind, one that I'll paraphrase as best as I can remember it: "Isn't it funny that as soon as they raised fees these institutions all of sudden wanted black people in them. That just tells you how institutionally racist universities are." This student, by linking the rise of fees in British academia to the widening participation policy, critiqued how the increase in black and ethnic minority students in the university system could be directly correlated to financial gain. Moreover, they located a temporality by which to understand a Brexit present that started in the late 1990s, in a period that we now mark as the intensification of neoliberalization as policy in the UK and across the world - what could be described as an ideology that purports the socialization of cost and the privatization of benefit.

Of course, there were other explanatory temporalities that I heard students evoke in the last four years in Goldsmiths. My students, who had affective connections to various sovereign national contexts around the world, all of which were former British colonies, often brought up Brexit in relationship to British imperialism and colonialism. These connections weren't articulated as a past linked to the present. Rather, they were described as ongoing imperial relationships that Britain had with their other national affiliations. The everyday racism they were experiencing in the UK and in the university, they felt, was amplified through Brexit discourse because these imperial relations were once again made explicit and being touted as the future. Explicit calls to renew and rejuvenate the commonwealth, for example, were experienced by my students as what some political pundits have described as Britain's attempt to create empire 2.0. ${ }^{5}$ For black, Asian, and ethnic minority students born in the UK, this discourse of "British empire rejuvenated" brought up experiences they had growing up in cities and towns across the country, where they

4. The Russell Group are a consortium of 24 British Universities. When founded in 1994, the group consisted of 18 universities with the mission to protect their interests as the "most prestigious" research intensive universities in the UK. https://russellgroup.ac.uk/about/our-universities/

5. Empire 2.0 is a term that has circulated in the media to describe the aspirational rhetoric of politicians who have supported Brexit. See, for instance, https://www.theguardian .com/politics/2018/nov/08/empire-fantasy-fuelling-tory -divisions-on-brexit. 
were subject to narratives that placed postcolonial countries like India, Pakistan, Nigeria, and Ghana (to name a few) as inferior and waiting for British leadership.

Brexit talk, with its violent, racialized animosity directed towards Eastern European workers, allowed black and ethnic minority students to voice yet another sentiment linked to the time-space of the Commonwealth that had been making its rounds in media and academic circles. This sentiment suggested that Britain, with its call to strengthen its ties with its former colonies through the Commonwealth in the post-Brexit period, would finally recognize their families' contributions in the UK. This idea, when voiced in classrooms by some students, sparked debate. Other students pointed to the Windrush Scandal and Grenfell Tower to demonstrate the fallacy of this sort of thinking. ${ }^{6}$ They argued that just because Eastern Europeans were being targeted didn't mean that long-settled black and brown communities in the UK would be held exempt or, for that matter, embraced. They argued that an amplification of discrimination against Eastern Europeans in the Brexit moment signalled something important about how citizenship is consolidated through discourses that legitimate British middle-class whiteness as the key determinant for belonging.

All told, Brexit opened up for students to engage with and articulate several temporalities - punctuated by specific historical events - by which to understand the racism that its discourse had fuelled or has brought to the surface. Moreover, it pushed them to locate their experiences in the university as steeped in everyday discrimination. BAME students at Goldsmiths and, eventually, in other institutions across the UK, put reading lists, marking, pedagogy, and the everyday space of the university under scrutiny. These efforts to "decolonize" the university, of course, had precedent in the UK prior to Brexit. In 2015 Oxford, taking up the mantle of student activists in South Africa, began their own Rhodes Must

6. The Windrush Scandal refers to events that unfolded in 2018, when BAME citizens - and long-term residents who arrived in the postwar period-were wrongly detained and, in some cases, deported by the UK Home Office. Grenfell Tower was a social housing complex in North Kensington, London that burned down in summer 2017. The fire killed seventy-two people, the majority of whom were BAME. In the inquest it was found that the government had been lethally negligent in the upkeep and renovation of the building.
Fall movement. ${ }^{7}$ What marked the public articulation I saw at Goldsmiths as distinct from this movement was the broad platform of demands that the Goldsmiths students developed. By early 2019, students who had been voicing discontent and critique since I had arrived occupied one of the institution's main administrative buildings. Calling themselves Goldsmiths Anti-Racist Action (GARA), they formulated a list of demands which included a campus-wide curriculum review, a revamp of the university's complaints procedures, the reinstatement of scholarships for Palestinian students, and better housing for the cleaners and security guards on campus, the majority of whom identify as BAME. Their platform went beyond decolonial efforts insofar as they included a transnational and class element to their anti-racist activism.

Some staff responded with alarm. The term racial crisis was used by several of my colleagues to describe the complaints and demands of the student activists. Crisis is a temporal claim that has the tendency to erase shared histories while simultaneously linking action in the present to future stability. "Crisis," when used in the context of BAME student activism in the midst of Brexit unfolding, exemplifies what it means for Britain to claim a sovereignty rooted in colonial and imperial formations while simultaneously occluding this history. By relating the demands that BAME students brought to the table as a "racial crisis," my colleagues enacted a temporality of forgetting and paved a quick path to the future through solution-oriented action. The danger in that sort of thinking, of course, is that the moment that the complaints of the students are seen as something that needs to be resolved, the tendency is to turn towards bureaucratic forms of repair and solution rather than a deeper engagement with the ways the university and its staff are implicated in durable forms of coloniality (see Ahmed 2012 for a deeper engagement with how complaints of racism are dealt with in the university).

7. The Rhodes Must Fall Movement, which started in Cape Town, South Africa in 2015, offers a window into what is at stake when the symbols of imperialism - in this case statues of British magnate and empire builder Cecil Rhodes - are linked to the experiences of postcolonial and BAME students in the university. https://www.theguardian .com/uk-news/2016/mar/16/the-real-meaning-of-rhodes -must-fall 
The GARA occupation lasted for four months and culminated in the summer of 2019, when senior management at the university agreed to honor the majority of their demands. The university leadership has yet to fulfill the majority of them. The GARA occupation has since spurred on other actions and occupations across the UK. ${ }^{8}$ These actions, all of which call for a greater attention to racialized inequality in higher education, were engendered by a shift in political discourse brought about by Brexit and its calls for a return to glorious empire with all of its racist connotations. As such, we might imagine that Brexit has created the conditions for a new generation of anti-racist activists to emerge: a generation that has an international and intersectional sensibility around the afterlives of colonial and imperial rule and that locates their struggle in the spaces that imagine themselves liberal and, therefore, post-racial.

8. See, for instance, the Student Union statement on antiracist occupation at Warwick. https://www.warwicksu .com/news/article/warwicksu/SU-statement-on-student -occupation-2019/

\section{References}

Ahmed, Sara. 2012. On being included: Racism and diversity in institutional life. Durham, NC and London: Duke University Press.

Boliver, Vikki. 2016. "Exploring ethnic inequalities in admission to Russell Group universities." Sociology 50 (2): 24766.

Green, Sarah (ed.), Chris Gregory, Madeleine Reeves, Jane K. Cowan, Olga Demetriou, Insa Koch, Michael Carrithers, Ruben Andersson, Andre Gingrich, Sharon Macdonald, Salih Can Açiksöz, Thomas Hylland Eriksen, Cris Shore, Douglas R. Holmes, Michael Herzfeld, Marilyn Strathern, Casper Bruun Jensen, Keir Martin, Dimitris Dalakoglou, Georgos Poulimenakos, Stef Jansen, Čarna Brkovič, Thomas M. Wilson, Niko Besnier, Daniel Guinness, Mark Hann, Pamela Ballinger, and Dace Dzenovska. 2016. "Brexit referendum: First reactions from anthropology." Social Anthropology 24 (4): 478-502.

Holland, Sharon Patricia. 2012. The erotic life of racism. Durham, NC: Duke University Press.

Mullings, Leith. 2005. "Interrogating racism: Toward an antiracist anthropology." Annual Review of Anthropology 34: 667-93.

Stoler, Ann Laura, ed. 2013. Imperial debris: On ruins and ruination. Durham, NC: Duke University Press.

Dr. Ethiraj Gabriel DatTATREYAn is a Senior Lecturer in the Department of Anthropology, Goldsmiths, University of London. His published writings, films, and exhibitions engage with urban life, digital media circulations, youthful becoming, racialized difference, and gendered performance. His forthcoming book, The globally familiar: Digital hip hop, masculinity, and urban space (Duke University Press, 2020), documents the ways in which working class young men productively take up hip hop as a means to reflexively and productively self-fashion themselves as gendered and racialized subjects in India's rapidly changing capital city.

Ethiraj Gabriel Dattatreyan Goldsmiths, University of London

Department of Anthropology

34-40 Lewisham Way

London SE14 6NW

$U K$

g.dattatreyan@gold.ac.uk 